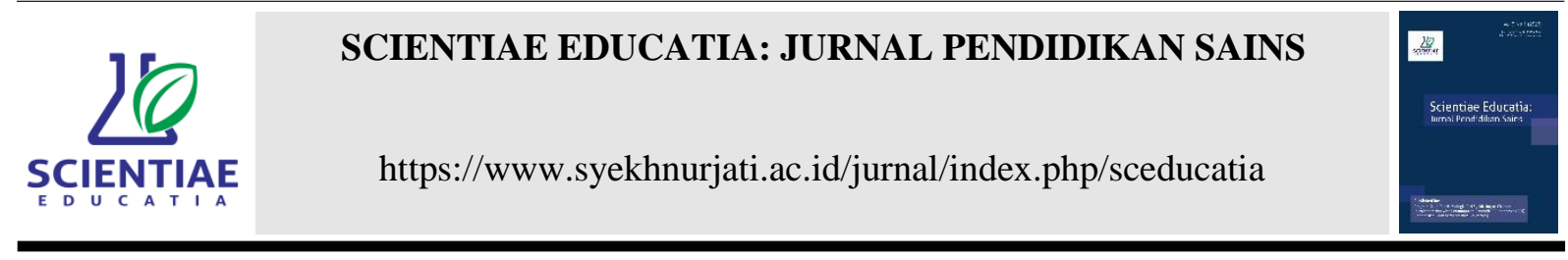

\title{
Differences in Students' Thinking Skills in Making Decisions Through Online Learning Based on Google Classroom Applications on Ecosystem Materials
}

\author{
Nilawati*, Dewi Cahyani \\ Department of Biology Education, Faculty of Education and Teacher Training, IAIN Syekh Nurjati Cirebon, \\ Indonesia
}

${ }^{*}$ Corresponding author: J1 Perjuangan by Pass Sunyaragi Kesambi Kota Cirebon, Jawa Barat, Indonesia E-mail addresses: nilaalin121@gmail.com

\begin{tabular}{|c|c|}
\hline article info & a b s t r a c t \\
\hline $\begin{array}{l}\text { Article history: } \\
\text { Received: } 02 \text { October } 2021 \\
\text { Received in revised form: } 20 \\
\text { October } 2021 \\
\text { Accepted: } 22 \text { December } 2021 \\
\text { Available online: } 31 \text { December } \\
2021 \\
\text { Keywords: } \\
\text { Online learning } \\
\text { Decision-making } \\
\text { Ecosystem material } \\
\text { Thinking skills }\end{array}$ & $\begin{array}{l}\text { Independent learning needs to be done in online learning to search, } \\
\text { observe, and discover until you conclude what has been learned. } \\
\text { Provisions in the } 21 \text { st century that students must have, namely } \\
\text { critical thinking and solving problems, it is necessary to make } \\
\text { decisions to identify and decide the best decisions in the future, } \\
\text { students are trained to solve a problem and must be able to make } \\
\text { decisions. Ecosystem material with natural cases identified problems } \\
\text { until reaching the right solution is one of the successes of decision } \\
\text { making. The purpose of this study is to describe the online learning } \\
\text { process based on the google classroom application for ecosystem } \\
\text { materials and describe the differences in decision-making skills } \\
\text { between male and female students through online learning based on } \\
\text { the google classroom application for ecosystem materials. The } \\
\text { method used in this research is to use a quantitative approach with a } \\
\text { comparative research design. The research was conducted at SMAN } \\
1 \text { Jamblang with a sample of } 14 \text { male students and } 14 \text { female } \\
\text { students. The quota sampling technique is a comparative } \\
\text { quantitative method using data collection techniques and } \\
\text { instruments in observation sheets, multiple-choice questions, and } \\
\text { documentation: statistical descriptive analysis techniques, inference, } \\
\text { observational analysis, and analysis of decision-making skills. The } \\
\text { research process begins with determining the study's time and } \\
\text { location and drawing conclusions. The online learning process for } \\
\text { ecosystem materials is in the range of } 51 \% \text { - } 75 \% \text { (good } \\
\text { implementation), and there are significant differences in decision- } \\
\text { making skills between male and female students through online } \\
\text { learning based on the google classroom application on ecosystem } \\
\text { materials for class X MIPA } 1 \text { at SMAN } 1 \text { Jamblang. } \\
\text { 2021 Scientiae Educatia: Jurnal Pendidikan Sains }\end{array}$ \\
\hline
\end{tabular}

\section{Introduction}

The coronavirus disease 2019 (Covid-19) pandemic is not the main obstacle in Indonesia's education world, especially in the applied learning process. Therefore, state regulations to maintain distance in preventing the spread of covid-19, teachers strive to keep the learning process optimally supported by supporting technology for online learning. One of the Covid-19 pandemic impacts is the decline in student learning outcomes. On the other hand, teachers are never weary of giving the greatest education possible for their students. 
One of the characteristics of online learning is the ability to learn independently. Students will search and find until they come to their conclusions about what they have learned while learning online. This independent learning is directly involved in identifying what needs to be learned in the learning process by its own thinking power (Handarini et al., 2018).

The importance of decision-making skills is that humans can solve problems and make decisions almost every day, whether at home, classroom, at work, etc. Solving these problems usually involves systematic and objective steps, as well known as the scientific method. Decisionmaking in problem-solving through the thinking process is used to identify and decide what the best decision is going forward. Decision-making skills are one of the soft skills that students must possess. In order to be able to carry out decision-making skills well, it is necessary to have a critical analysis that includes compiling related questions (Wulandari \& Rasmawan, 2016). Communication (communication), Collaboration (collaboration), Critical Thinking and Problem Solving (critical thinking and problem solving), and Creativity and Innovation (creativity and innovation) were important requirements for students in the twenty-first century (Siti, 2016). This provision is also supported by research by Resti and Rendi (2018) that 21st-century skills can increase cooperation in a group to solve a problem and a sense of tolerance for differences of opinion among friends and can try to think critically and creatively solve problems about linking things.

Critical analysis in a decision-making skill possessed by each student is different, even though the choices they face are the same. Gender is one of the factors that cause differences. Critical analysis can be owned by all individuals, both men, and women. Differences between women and men who are socially constructed, not based on mere biological differences, are called gender (Hatifah, 2015). Based on the results of the analysis of gender differences in creativity both in the form of creative thinking and creative writing, it is stated that women tend to have higher levels of ability with a mean ratio between men and women, namely 114.75:107.08 for creative thinking skills and 31,31:21,09 for creative writing ability (Aziz, 2006). According to the author of Suyadi's statement in his journal, describing that the neuroanatomy of the brain as seen from the Corpus callosum in women is thicker than men so that women can do more things simultaneously than men, that is, they can complete many jobs simultaneously, but on the contrary, than men generally write first then explain to others or describe first and then tell stories (Suyadi, 2018).

Other brain areas, such as the corpus callosum, hypothalamus, inferior parietal lobe (lower parietal lobe), and hippocampus, show differences between male and female brains. These anatomical differences will have implications for different ways and styles of doing things, including learning to make decisions (Amin, 2018). Decision-making in the biology learning process can be carried out through entrepreneurship-based environmental pollution materials according to research by Sanjaya et al. (2019) of $77 \%$ because they choose one or more options and make estimates that will occur students solve environmental pollution problems with high decision making.

Based on this background, researchers are interested in conducting research related to decision-making skills based on gender. This study describes the online learning process for ecosystem materials based on the Google Classroom application. This research is expected to be able to shape the personality of students who have more systematic thinking skills in making decisions between male and female students on ecosystem materials through an online learning process using the Google Classroom application in class X. 


\section{Method}

The population in this study were all students of class X Science Department at SMAN1 Jamblang. They are a class of X IPA 1 to X IPA 6 as many as 216 students, with 84 male students and 132 female students. The sampling technique used was quotas, namely, determining samples from the population-based on certain characteristics until the desired quota number is met (Sujarweni, 2020). The class used in this study is X IPA 1, with the criteria that some of the students respond well during online learning and actively ask questions and decide their choices well, which is known from student activity in the organization. The sample is categorized into classes A and B with the same quota fulfillment, namely 14, 14 male students of class A and class $\mathrm{B}$; there are 14 female students, then eight students were eliminated based on the delay in filling out the questions.

The research approach used is a quantitative approach aimed at producing differences in the decision-making skills of male and female students influenced by online learning using the Google Classroom application on the Ecosystem material for X grade. The research design used is comparative research, namely the comparative method to compare one or more variables in two or more different samples or at different times (Sugiyono, 2010). This study aims to produce differences in decision-making skills (decision making) online learning in two groups, namely groups of male and female students based on the instrument of observation sheets and questions. The study results will be described statistically to describe the results of observations and the final results of tests on online learning using the Google Classroom application in class X MIPA 1 and describe the results of the differences. The description will be explained systematically from the beginning to the end of the data collection process based on various information and facts found from the research.

This technique of collecting data through observation aims to find out the online learning process taking place while carrying out teaching and learning activities on ecosystem materials in class X MIPA 1 online using the Google Classroom application. The observers in this study were two people who were conducted online at home because it is known that the Covid-19 graph increased by 1,282 positive cases in Indonesia (news.detik.com), so this research can suppress the spread of the virus. This observation sheet is equipped with online learning process indicators, according to Handarini (2018). These indicators are not only in favor of students but also for teachers. Meanwhile, the Multiple Choice (PG) test measurement technique which contains HOTS elements, aims to measure decision-making skills by describing them based on percentage analysis. The data obtained are student answers that meet the decision-making indicators, according to Wulandari and Rasmawan (2016). This research has fulfilled the prerequisites as an instrument because it has been validated, tested, and analyzed.

Table 1. Indicators of decision-making skills

\begin{tabular}{ll}
\hline \multicolumn{1}{c}{ Indicator } & \multicolumn{1}{c}{ Indicator Description } \\
\hline Determination of several choices & $\begin{array}{l}\text { Taking into account the circumstances of all available } \\
\text { alternatives }\end{array}$ \\
Best Alternative Selection & $\begin{array}{l}\text { Analyze, synthesize, evaluate, determine one of the } \\
\text { alternatives that have been considered previously with } \\
\text { accurate reasons }\end{array}$ \\
Decide on the selected option
\end{tabular}




\section{Result and Discussion}

There is only one difference in the online learning process of observing ecosystem materials: observer I's overall score is 29 , while observation II score is 28 . The observer's profit score is divided by the total value according to the analytical technique given in the previous chapter overall is $48 \mathrm{As}$ a result, observer I percentage value is 29 divided by 48 times 100 percent, while observer II percentage value is 28 divided by 48 times 100 percent, giving the following findings.

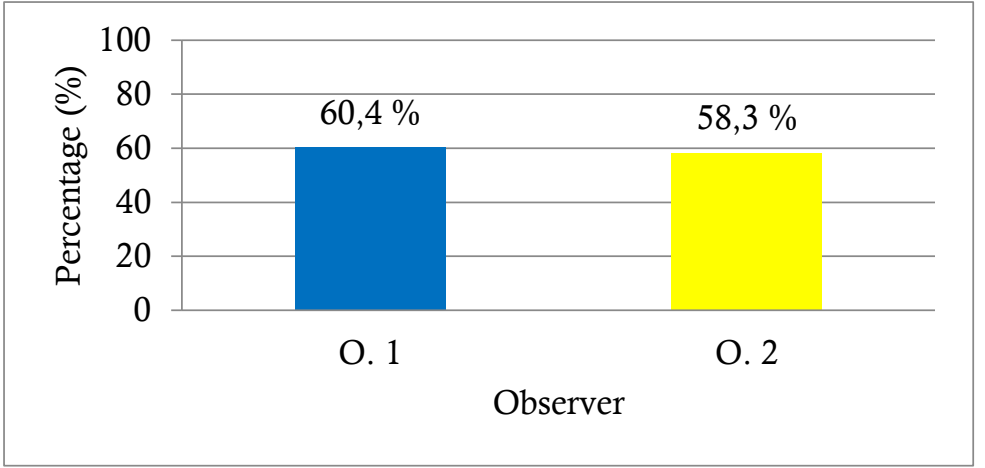

Figure 1. Percentage of observation results of online learning process google classroom application

The online learning process for ecosystem material for X grade MIPA 1 at SMAN 1 Jamblang through the google classroom application from observer observations obtained an average value of 59.4, from each observer I and II, respectively $60.4 \%$ and $58.3 \%$. Thus, the interpretation of Trianto (2010) that in the range of $56 \%-75 \%$ can be said to be good in implementation, so that the discussion based on each indicator can be seen as follows.

Based on the observation that the first indicator, they are student motivation in online learning as seen from attendance, has an average of 2,625 in online learning using the Google Classroom application. This is supported by research from Sriwiyati (2021) that online learning using the google classroom platform has a large increase in the aspect of student participation, from $37.1 \%$ in the first cycle to $66.7 \%$ in the second cycle.

The second indicator is the understanding of learning to use the application. In this study, several students expressed problems using the Google Classroom application when the online learning process for ecosystem materials was in progress so that the results of the study were categorized as good enough to understand, and this happened because the Google Classroom application had the privilege of being able to connect. There are many Google services simultaneously in order to provide recommendations for educational institutions to switch to a paperless system, besides that the creation and assignment of assignments can be completed via Google Drive while using Gmail to create notifications in Google classrooms that are used during the online learning process (Mahrita, 2019).

The third indicator is the ability to communicate interpersonally between students and teachers and students during the online learning process for ecosystem materials, obtained poor results, which have an average value of 1 because those students tend to passively communicate through the Google Classroom application. In implementing online learning for ecosystem materials, the teacher only includes instructions for students to listen to the videos and then do practice questions. This renders students uninterested in talking online using the Google Classroom program, which is in stark contrast to face-to-face learning, in which nearly every student in class X MIPA 1 actively questions, answers, and exchanges opinions with others and the teacher. Students transitioning to the school level, which was previously applied face-to-face and later became online learning, do not know much about online learning applications. However, if it is done continuously, students will be proficient in operating the Google 
Classroom application. This is in line with Arifin and Bunyamin's research (2020) that if you use it often, you will become more proficient, so it is natural that at the beginning of using the Google Classroom application, you feel less confident in its operation. Therefore, it is necessary to conduct training for new students to provide effective and efficient elements in improving the teaching and learning process (Rakhmawati et al., 2020).

Students' understanding of ecosystem material during the online learning process based on the results of the fourth indicator observation observed through the scores on the exercise assignment, the average result was 3.1. In line with Arifin and Bunyamin's research (2020), students' understanding of the material can be seen through their learning outcomes; that is, if the learning outcomes are good, it indicates that students have understood the material presented by the teacher. It is known that students' understanding of ecosystem materials through the Google Classroom application is fairly good. This is following the findings of Andini et al. (2019), who found that a blended learning approach based on the Google Classroom application increased students' cognitive abilities by 84 percent. In addition, the implementation of learning using the Google Classroom application combined with the video application (Youtube) makes students better understand the concept of the ecosystem conveyed by the teacher during online learning, because according to research by Nur and Sukmawati (2021) that Google Classroom-based learning will be more effective if there are assistance other digital applications that can help and strengthen online learning.

The ability of students to interpret conclusions is the fifth indicator, one of which gives a decision when implementing online learning using the Google Classroom application; the average result is 2.25 , which is categorized as good enough. The ability of students to interpret conclusions and make decisions can be seen in the practice questions (worksheet) sent through the Google Classroom application, that are X grade of MIPA 1 at SMAN 1 Jamblang is quite good because of the implementation of learning that is quite effective using the google classroom application. Supported by the research of Sabran and Edy (2019) that evaluates the implementation of learning using the google classroom application, the category is quite effective with a tendency of $69.01 \%$.

Based on the analysis of the five decision-making skills indicators, the results show that students are skilled in determining several alternative choices, to 5 male students and six female students on indicator 1, and students are skilled in selecting the best alternative, to 2 male students and three female students on indicator 2. female students, on the third indicator skilled students in making choices, namely two male students and three female students, on the fourth indicator skilled students in determining impact, namely five male students and one female student, and on the fifth indicator skilled students in assessing the choices determined, namely four male students and six female students. The outcomes of disparities in decision-making skills are shown in the graphic below to be differentiated as a whole.

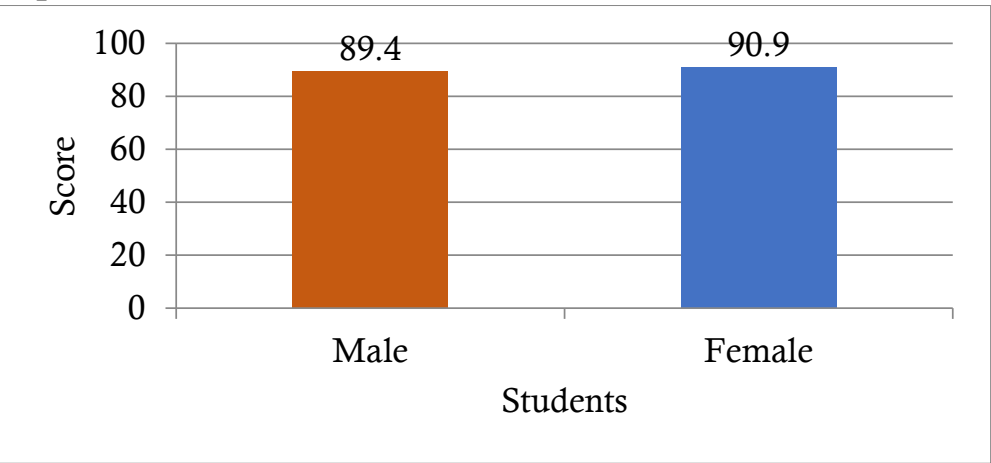

Figure 2. Differences in decision-making skills (decision making) of male and female students 
Based on Figure 2, it is known that students in class X MIPA 1 SMAN 1 Jamblang have variances in decision-making skills between male and female students, with male students' decision-making skills being 89.4 percent lower than female students' decision-making abilities being 90.9 percent lower.

One aspect, namely one's intelligence in making decisions connected to grasping the notion of the ecosystem material being investigated, is responsible for this study's disparity in decisionmaking abilities. Gender disparities in student learning processes can result in physiological and psychological differences. As a result, there are various variances between male and female pupils when it comes to studying ecological material (Agung et al., 2013). This learning gap is determined by a person's IQ. Men's intelligence of the mindset of decision-making skills in class X MIPA 1 is known to be lower than women's. This occurs because the number of neurons in the brain correlates with intelligence level, allowing action potential kinetics and efficient information transfer from input to output in cortical neurons (Anwar et al., 2019).

The human brain has more than 10 billion nerve cells (neurons) which are worked on by about 30 trillion cells to control every function of the body's metabolism, thus enabling us to think, solve problems, and make decisions. The transmission of electrical impulses or signals from one neuron to another depends on the activity of certain chemical compounds in the brain known as neurotransmitters that have specific effects on brain function and mood. The brain has chromosomes, so the difference between men and women is also determined by the type of chromosome. Chromosomes are part of the cell that contains hereditary traits found in the cell nucleus. Humans have 22 pairs of chromosomes, plus two sex-determining chromosomes for a total of 46 chromosomes. Males have unpaired sex-determining chromosomes, whereas females have paired chromosomes, specifically XX (Kris, 2018).

The brain captures all stimuli to be understood through the work of nerve cells, neural circuits, and neurotransmitters, the part of the cerebrum (cerebrum) functions as a center for mental activities such as memory (memory), intelligence (intelligence), and also awareness and consideration so that its existence allows individuals to produce thinking skills (Syahrudin, 2018). If someone has learned something, he will experience the overall behavior in attitudes, skills, and knowledge (Agung et al., 2013).

Ecosystem content contains exploratory theory and evidence directly available in the natural environment, enhancing students' decision-making abilities. The concept of natural knowledge has been shown in prior studies to increase decision-making skills by 45 percent (Badarudin, 2017). As a result, the ecosystem material is appropriate for assessing pupils' decision-making abilities.

A person can make decisions from the age of 8 years because children are aware that everyone is aware of other people's perspectives so that awareness affects their views and the views of others. It is possible to judge the intents, aims, and actions by locating oneself and others. The children can form a coordinated chain of perspectives but cannot simultaneously abstract these processes at a reciprocal level (Desmita, 2012).

Decision-making skills using scientific analysis based on logic, considering all available data, all possible alternatives, and following the steps of decision making. This is supported by Desmita's (2012) theory that at adolescence, a person can think abstractly and hypothetically to think about something that will or might happen (something abstract) and integrate what has been learned in making plans front.

Decision-making skills are also called a process in deciding which actions to take involving choices, so this research contains multiple-choice instruments to see the decision-making skills taken in ecosystem materials. This statement is supported by previous research that decision- 
making skills in the process identify good choices from bad choices according to the criteria that have been set in action (Karunia, 2018).

The types of thinking skills a person is divided into 4, namely problem-solving skills (problemsolving), decision-making skills (decision making), critical thinking skills (critical thinking), and creative thinking skills (creative thinking). Someone who has high creative thinking skills indicates that the person can think critically, be able to conclude, and solve problems. Someone who can make decisions indicates that that person is able to solve problems, so the instrument used is based on HOTS accompanied by solving a problem on ecosystem materials.

On the other hand, Thahir's research (2014) shows that women use emotional focus while men focus on problem-solving so that when facing exams, men can look calmer in doing exam questions, while women look busy turning left-exactly looking for a cheat from a friend next door. So in this study, men are more skilled in making decisions.

These decision-making skills can change following the development of mindsets and environmental influences. A person's decision-making skills are very dependent on the position of the decision-maker, the situation in which the decision-maker is located, the position of the problem faced and must be solved, the condition of the decision-maker, which includes his ability and strength to deal with the problem, as well as the goals to be achieved from the decisionmaking process (Novita \& Endah, 2018).

According to the Qur'an (Surah Al-Alaq:1-5) and concern for Hamka concerning gender equality, everything comes from a clot of blood that comes from a clot of semen (derived from a fine filter of human food taken from the earth), hormones, calories, vitamins, and various other substances derived from vegetables, staple foods, fruits, meat, and so on (Juono, 2015).

According to Legato's research published in the journal Sri (2013), the distinguishing element for gender disparities is language and abilities; parents prefer to interact with women over males. Therefore female students' vocabulary mastery is higher than male students. This comparison of the two genders makes women appear to be more active in speaking than men. It was also explained in the research of Shaywitz in the journal Agung et al. (2013) that during a phonological task, male brain activation focused on the left frontal gyrus, whereas females showed a more diffuse pattern of activation involving nerves in both the left and right inferior frontal gyrus. Therefore, the information provides evidence of variations in the level of language processing in males and females. In the book, The Female Brain (2006), Brizendine says that women utter 20,000 words per day compared to men, who only use an average of 7,000 words per day. This is because estrogen levels press the buttons in the brain to talk more and interact with others (Brizendine, 2010).

The factors of decision-making skills are divided into two, namely internal and external factors. Internal factors include anxiety related to rushing time in working on questions and experience having worked on similar questions, while external factors include quotas and aspirations from searches on Google and aspirations from other people. This statement is supported by research that explains that internal factors that can influence decision-making skills come from interests and experience, while external factors include encouragement from other people into consideration (Alika et al., 2017).

\section{Conclusion}

The online learning process on ecosystem materials using the google classroom application in class X MIPA 1 SMAN 1 Jamblang is good, and there are differences in decision-making skills between male and female students in making decisions (decision making) through online learning based on the google classroom application on ecosystem materials class X MIPA 1 at SMAN 1 
Jamblang is $89.4 \%$ (male students) and $90.9 \%$ (female students). Therefore, the decision-making skills of male students are smaller than the decision-making skills of female students.

\section{References}

Agung, P., Zubaidah, S., \& Mahanal, S. (2013). Differences in Thinking Ability and Biology Learning Outcomes of Class X Sma Negeri 7 Malang Based on Gender With the Application of Jigsaw Strategy. Journal of Biological Education 1(1)

Alika, et al. (2017). Urbanites edition 4 - the decision-making process for choosing a university and study program: A case study on students of the faculty of technology and design (FTD). Jaya Development University Printing.

Aminuddin, L. (2016). Gender Concepts and Issues In Islam. Journal of Ihya Al-Arabiyah, 2(1).

Andi, T. (2014). Differences in Coping Mechanisms between Male and Female Students in Facing Semester Exams at the Tarbiyah Faculty of IAIN Raden Intan Lampung. Journal of Guidance and Counseling 1(1)

Andini et al. (2019). Application of google classroom application-based blended learning to improve the cognitive ability of class $\mathrm{X}$ students on ecosystem materials at SMAN 1 Ciwaringin. Indonesian Journal of Natural Sciences, 2(2), 85 - 98.

Arbain, J. (2015). Gender Thinking According to Experts: A Study of the Thoughts of Amina Wadud Muhsin, Asghar Ali Engineer, and Mansour Fakih. Sawwa Journal, 11(1).

Arifin \& Benjamin. (2020). Effectiveness of Online Learning Media Through Google Classroom. Journal of Islamic Education, 11(2).

Ariyana, Y., Bestary, R., Yogyakarta, U. N., \& Mohandas, R. (2018). Learning Handbook Oriented on Higher Order Thinking Skills. Directorate General of Teachers and Education Personnel: KEMENDIKBUD.

Awalludin. (2018). The Effectiveness of Decision-Making Models in Learning to Write Persuasive Paragraphs for Class X Smk Trisakti Baturaja. Journal of Bindo Sastra, 2(1), 159167.

Aziz. (2008) Why Women Are More Creative Than Men?. Journal of UIN Malang, 1(1).

Brizendine, L. (2010). Female Brain. Phoenix Publishing Project

Desmita. (2012). Developmental Psychology of Students. PT Teen Rosdakarya

Handarini O. I., \& Wulandari S. S. (2018). Online to draw causal claims from non-randomized studies of primary care interventions. Journal of Office Administration Education (JPAP). 35(5), 639-643.

Herson, A. (2014). The decision-making process for developing the quality of madrasah Herson Anwar. Journal of Islamic Education, 8(1).

Juono. (2015). Gender Equality in Islamic Education. Journal of Islamic Studies. 15(1).

Khairunnisa, R., \& Setyaningsih, N. (2017). Metacognition Analysis of Students in Social Arithmetic Problem Solving in terms of Gender Differences. Proceedings of the Second National Conference on Mathematics Research and Learning (KNPMP II) Universitas Muhammadiyah Surakarta, 18 March 2017

Kris, T. (2018). Brain \& behavior. ANDI Publisher

Mahrita, H. J. (2019). The Use of Google Classroom Applications in Mathematics Learning Think Pair Share Type at Smkn 3 Banjarmasin. Proceedings of SenpikaII, FKIP Mathematics Education Study Program, Lambung Mangkurat University, Banjarmasin, 12 October 2019.

Mandella, S. et al. (2021) Early Scientific Reasoning Ability of High School Students based on Gender in Ecosystem Materials. Journal of UNJA, 7(2).

Maulidya, A. (2018). Thinking and problem-solving. Journal of Arabic Language and Literature Education 4(1) 
Mindra, P. (2020). Corona Chart July 13: New Cases Drop, Patients Recovered Soared. [Online] Accessed from the news.detik.com website on July 13, 2020.

Netty, K. (2015). Sex Roles, Gender and Occupational Bias. Pamator Journal, 8(2).

Novianti, M. (2020) Differences in Student Learning Outcomes Based on Gender in Biology Subjects. Journal of Equalita, 2(1).

Novita \& Endah (2018). The Role of Gender in Decision Making in the Reformation Era in Police Institutions. Journal of M-Progress, 8(2).

Ratu, H. D. (2015). The Effect of Gender Relations and Decision Making on the Performance of State Junior High School Teachers (SMP Negeri) in South Bekasi District, Bekasi City. Journal of Educational Management, 6(2).

Rakhmawati, P. (2021). Google Classroom Based Learning, Geoogle Meet And Zoom Teachers SMP Negeri 2 Batubara. Journal of Community Service, 1(4).

Rofiq, A. A. (2016). The Importance of Social Decision Making Skills for Junior High School Students. Psympathic: Scientific Journal of Psychology, 2(2), 175-184.

Sabran \& Edy. The effectiveness of Google Classroom as a learning medium. Proceedings of the National Seminar on Research Institute of Makassar State University on Dissemination of Research Results through Optimization of Syntax and Intellectual Property Rights.

Sadikin, A., Hamidah, A., Pinang, K., J1, M., Ma, J., Km, B., Indah, M., Jaluko, K., Kode, KM, \& Indonesia, P. ( 2020). Online Learning in the Middle of the Covid-19 Pandemic (Online Learning in the Middle of the Covid-19 Pandemic). Journal of Biological Education, 6(1), 214224.

Samsul Anwar, et al (2019). Male or Female, Who is Smarter in the Learning Process? A Evidence From The Survival Analysis Approach. Journal of Psychology, 18(2), 281-296.

Sanjaya, M.S.M, Wahidin, Maryuningsih Y. (2019). Application of Entrepreneurship-Based Biology Learning on Environmental Pollution Materials to Improve Students' DecisionMaking Skills. Indonesian Journal of Natural Sciences, 2(1).

Sari, M. (2015). Critical Thinking in Making Decisions. Journal of Nursing. 8(2).

Septikasari Resti \& Frasandy Nugraha Rendy (2018). 21st Century 4c Skills in Basic Education Learning. Journal of Tarbiyah Al-Awlad, 8(2), pages 112-122

Setiawan, Y. (2012). Gender Role in Audit Decision Making. Scientific Journal of Accounting Students, 1(2).

Siagian. (1990). Decision Making Theory and Practice. PT. Template: Jakarta.

Soenarko, K. G., Andayani Y., \& Edi, J. (2018). Decision Making Skills and Chemistry Learning Outcomes of Students at SMA/MA Negeri Mataram in applying learning methods. MIPA Incandescent Journal, 13(2).

Sri, Y. (2013). Gender Differences in Language Mastery from the Perspective of Educational Psychology. Scientific Journal of Education 13(1)

Sriwiyati. (2021) Online Teaching to Increase Student Participation and Study Completeness in Biology Subjects in High School with the Google Classroom Platform. Edumaspul Journal, $5(1)$.

Sugiyono. (2010). Quantitative, qualitative, and r\&d research methods. Alfabeta.

Sukmawati. (2021). Implementation of the Utilization of Google Classroom in the Online Learning Process in the Industrial Era 4.0. Online Creative Journal, 8(1).

Sulistyorini. (2009). Biology 1. In Biology 1 for Senior High School/Madrasah Aliyah Class X. Jakarta: Ministry of National Education.

Suyadi. (2018). Brain Differentiation of Male and Female Kindergarten Teacher Nyai Ahmad Dahlan Yogyakarta: Study of Early Childhood Islamic Education from Gender and Neuroscience Perspective. Journal of Gender Studies 13(2). 
Syahruddin, A. (2018). Differences in brain structure and learning behavior between men and women; explanation in neuroscience and philosophy. Indonesian Philosophy Journal 1(1)

Trianto. (2010). Integrated Learning Model. Earth Literacy.

Wiratna, S. (2020). Research methodology. New Press Library.

Wulandari, S., \& Rasmawan, R. (2016). Description of Decision-Making Skills in Environmental Pollution Materials for Chemical Education Students, Fkip Untan. Untan's Journal, 1(1), 1-12. 